\title{
Sampling methods for assessing the diets of Atlantic puffin chicks
}

\author{
Michael S. Rodway, William A. Montevecchi* \\ Departments of Biology and Psychology, Memorial University of Newfoundland, St. John's, Newfoundland, Canada A1B 3X9
}

\begin{abstract}
Three methods for sampling the diets of Atlantic puffin Fratercula arctica chicks were compared and evaluated. Prey-carrying puffins were captured in mist-nets, or observed with a telescope or with unaided eyes. Prey samples collected in mist-nets yielded higher proportions of gravid capelin Mallotus villosus than did samples obtained visually. Telescopic samples produced higher estimates of the numbers of larval fish landed by puffins (larval fishes are often lost when food-laden birds are caught in mist-nets), and yielded underestimates of the lengths of male capelin. Slight correction factors made the 3 prey sampling methods comparable. Visual sampling procedures had the advantages of creating less disturbance and allowing puffins to deliver food to chicks. Use of telescopic sampling is, however, dependent on colony topography. Forage fishes, heavily dominated by 2 -yr-old capelin, made up $88 \%$ and $98 \%$ of the frequency and mass, respectively, of the prey delivered to puffin chicks. Small prey (larval capelin and sandlance Ammodytes spp., hake Urophycis tenuis, crustaceans) were most commonly fed to young chicks. Gravid and male capelin tended to be more commonly fed to chicks midway through the nestling period, a time of rapid growth. Spent female and immature capelin were fed more commonly to older chicks. The lengths of gravid capelin tended to increase through the nestling period. Gravid and spent female and male capelin and sandlance fed to puffin chicks were shorter in 1992 than in 1993 or 1994. Successful puffin chicks on Great Island, Newfoundland, Canada, were fed an average of $1105(\mathrm{SD}=435)$ prey items weighing $2812 \mathrm{~g}(\mathrm{SD}=579)$ equivalent to $12506 \mathrm{~kJ}(\mathrm{SD}=2391)$. Extrapolation of these findings suggests that the population of Atlantic puffins in Newfoundland consumes about $8000+\mathrm{t}$ of forage fishes, mostly 2 -yr-old female capelin during a breeding season. Data on age-class and gender status of prey harvests by marine birds will provide needed input in energetics and trophic models.
\end{abstract}

KEY WORDS: Capelin - Puffin · Sampling prey · Seabirds · Trophic relationships

\section{INTRODUCTION}

Long-term studies of seabird feeding ecology are essential for understanding trophic dynamics. Quantification of temporal and spatial variation of the species, amounts and ages of prey harvested by seabirds is needed to model the bioenergetics and trophic relationships of marine communities (Weins \& Scott 1975 , Furness \& Cooper 1982, Barrett et al. 1994). Sampling seabird prey harvests often provides important information on the spatial, temporal and age distributions and abundances of prey that are difficult or impossible

\footnotetext{
- Addressee for correspondence.

E-mail: mont@morgan.ucs.mun.ca
}

to obtain with conventional methodology (Cairns 1987 , Montevecchi et al. 1988, Barrett et al. 1990). Dietary data are also useful in assessing oceanographic and anthtropogenic influences on prey conditions (e.g. Croxall 1989, Bertram \& Kaiser 1993, Montevecchi 1993, Bost et al. 1994).

Atlantic puffins Fratercula arctica are pursuit-divers that catch most of their prey within $30 \mathrm{~m}$ of the water surface (Piatt \& Nettleship 1985). They prey on 'forage' species, including juvenile pelagic fishes, such as herring Clupea harengus, juvenile and adult capelin Mallotus villosus and sand lance Ammodytes spp. (Barrett et al. 1987). At times, they prey on juvenile demersal fishes, such as gadids (Harris \& Hislop 1978). Food delivered to chicks at breeding colonies is carried con- 
spicuously crosswise in the bill and is relatively easy to collect or to identify visually (e.g. Barrett et al. 1987. Rodway 1994). When they are feeding chicks, puffins generally forage within $10 \mathrm{~km}$ of their colony but may range as far as 50 to $100 \mathrm{~km}$ or more (Harris 1984). Their prey harvests have proven useful in predicting pelagic fish recruitment in subsequent years (Hislop \& Harris 1985)

Capelin, a keystone species for large vertebrate predators in the northwest Atlantic, is an important prey of seabirds and is the predominant species fed to puffin chicks at colonies in eastern Newfoundland, Canada (Brown \& Nettleship 1984). Capelin have also been the target of a lucrative roe fishery initiated in eastern Canadian waters in 1972 (Carscadden 1984). Harvesting by fisheries, oceanographic variation, and the interactive influences of these on capelin distributions and movements could hold serious consequences for puffins and other large vertebrate predators in northwcst Atlantic food webs (Nettleship 1991, Regehr 1994, Montevecchi \& Myers 1995a).

A previous study of the foods delivered to puffin chicks on Great Island, Newfoundland showed that capelin was the dominant food in 1967-69 and in 1982-84 but not in 1981, when meals consisted primarily of small gadids, and puffins experienced reproductive failure (Nettleship 1991). As the type of prey harvested by Atlantic puffins varies within and between seasons and among colonies (Barrett et al 1987. Nettleship 1991, Anker-Nilssen 1992), long-term studies of seabird feeding ecology are necessary to better understand the dynamics of marine food webs.

The present study is the first in the northwest Atlantic to provide detailed information on changes in prey delivered to puffin chicks over entire nestling seasons. It also is the first study to systematically compare and evaluate different sampling techniques that are or can be used by researchers studying puffins or other alcid or seabird species that carry food conspicuously in their bills. Both aspects of the study have important implications for sampling methodology and bioenergetic modelling

We investigated the prey that Atlantic puffins delivered to chicks on Great Island. Specific objectives were to: (1) compare 3 methods of sampling prey carried by puffins - mist-netting, telescopic and unaided visual estimates of food delivered to burrows; (2) determine if prey composition differed between the north and south sides of the island; (3) analyze variation in prey composition within and among breeding seasons; (4) delineate the size distribution of major prey types and how it changed within and among breeding seasons; (5) quantify intra-and inter-seasonal changes in the sizes, conditions and amounts of capelin landed by puffins; (6) compare recent prey harvests with those in the early 1980 s and late 1960s; and (7) estimate the biomass and number of prey consumed by puffin chicks and adults during a breeding season in the northwest Atlantic.

\section{METHODS}

Study site. Great Island $\left(47^{\circ} 11^{\prime} \mathrm{N} 52^{\circ} 46^{\prime} \mathrm{W}\right)$ in the Witless Bay Ecological Reserve of eastern Newfoundland is the site of the largest Atlantic puffin colony in the western Atlantic (Rodway et al. 1996b, see also Nettleship 1972, Rodway 1994)

Food sampling. Food brought for chicks was sampled throughout July and August 1992 and 1993, and on 5 July and from 22 July to 8 August 1994. The proportion of food samples collected by different sampling techniques changed during the study. In 1992, most samples ( 7 of 9 ) were collected by mist-netting flying adults carrying food. A sample of 20 bill-loads was collected on most sampling sessions, which usually took 2 to $4 \mathrm{~h}$. To minimize disturbance, mist-nets were not used longer than $4 \mathrm{~h}$ in any session, and a few samples consisted of less than 20 loads. We mist-netted in the same area on the south side of the island throughout the season to avoid potential biases caused by changes in location.

Sampling prey by telescopic observations of puffins holding fish was begun in 1992 (2 of 9 samples) as a complement to mist-netted samples. This technique was attractive, because: (1) more samples could be identified in much less time than with mist-nets; (2) it was less disruptive, allowing adults to deliver food to chicks after identification; and (3) there was greater certainty that all prey items were seen than when a bird was mist-netted and prey scattered on the ground. Its main disadvantage was that prey was not collected and could not be weighed or measured. Also, unusual prey items were less likely to be identified. We were confident that common prey items were identified correctly. Telescopic sampling (13 samples) was used in preference to mist-netting (4 samples) in 1993, and was used exclusively in 1994 (5 samples).

Observation sites for telescopic sampling were placed within the colony about 10 to $15 \mathrm{~m}$ from a cliffedge or steep slope. A conspicuous observer (M.S.R.) prevented puffins nesting in the area from delivering fish to burrows. Puffins generally landed and stood on the cliff-edge, being reluctant to land except at an edge from which they could escape easily, while the observer was present. Prey held by each bird was then identified using a 15 to $60 \times$ zoom Bausch and Lomb telescope. Resolution was sufficient to count eyeballs on 'larval' fish 2 to $3 \mathrm{~cm}$ long Prey length was estimated to the nearest $\mathrm{cm}$ using bill depth as a referent. 
The line of puffins that would gather on the cliff edge was scanned methodically from left to right to insure that all birds with prey were sampled, not only those with conspicuous items. Once a sweep of all standing birds with prey was completed the observer moved away for about $10 \mathrm{~min}$ to allow them to deliver food to chicks. A new group could then be sampled by repeating the procedure until the desired sample size was obtained. Including breaks, it usually took 1 to $2 \mathrm{~h}$ to identify a sample of 50 bill-loads.

Telescopic observations were also conducted on the north side of the island to determine if prey composition varied by location. Samples paired by date on the north and south sides were taken on 6 days between 17 July and 29 August 1993. We varied the order in which locations were sampled to reduce potential biases caused by daily changes in prey composition.

A third method of food sampling was used in 1993 to monitor changes in prey composition throughout the season and to estimate the total amount of prey deliv. ered in one season to a known number of chicks. Dawn-to-dusk watches were made of prey delivered to a sample of 32 to 47 burrows (some chicks died, decreasing sample size through the season) on the south side of the island. Observations were made from a blind every $4 \mathrm{~d}$ from the start of hatching to the end of fledging. Identification of prey types was less reliable than with telescopic observations because limited time was available for identifying prey as birds delivered it to burrows. When birds entered burrows too quickly for prey identification, prey type was categorized as unknown ( $3.0 \%$ of 2570 loads). Prey size was estimated with reference to bill depth as for telescopic samples. Two size classes of small larval fish were used (2 to 4 and 4 to $6 \mathrm{~cm}$ ), and cottids were lumped with larval capelin and sandlance to simplify identification. Hyperiids were grouped in one 2 to $4 \mathrm{~cm}$ size class. We did not attempt to count numbers of tiny larval fish or crustaceans, unless numbers were very small or the bird stood around for a while. To assign numbers to uncounted larval or crustacean loads we used the average number counted per bill-load in telescopic samples for each size class.

Prey were identified (Leim \& Scott 1966, D. Methven 1985, pers. comm.) and, for capelin, classed by age, gender and reproductive condition whenever possible (Templeman 1948, Pitt 1958, Jangaard 1974). Small, transparent unscaled capelin and sandlance were classed as 'larval' fish, although capelin were collected before hatching in the current year and were thus almost 1 yr old (Templeman 1948, Pitt 1958). Larval capelin (I-group) and sandlance (O-group; Dalley \& Winters 1987) from mist-netted samples were identified to species, but could not be separated in telescopic or unaided visual observations, so proportions identi- fied in mist-netted samples were used to estimate those in telescopic and unaided visual samples. Partially scaled I-group capelin were identified in mistnetted and telescopic samples but not in unaided visual samples. Also, we were unable to reliably separate spent females from fully scaled immature capelin because we could rarely find signs of recent spawning (e.g. remnant eggs), and because size ranges of gravid and non-gravid females or immatures overlapped Thus, immatures and spent females were lumped into one category for analyses of prey composition. Partially scaled capelin (i.e. definite l-group) were separated from fully scaled immatures for length analyses, because only prey from mist-netted and telescopic samples were used in those analyses.

We estimated the mass of each prey item identified in telescopic and unaided visual observations by calculating the average mass per $\mathrm{cm}$ length class (see 'Results') of all measured prey. Unidentified loads were assigned a mass equal to the mean of other loads delivered on a particular day. Measured prey included all items collected in mist-netted samples as well as prey dropped by puffins and collected incidentally Total length was measured to the nearest $\mathrm{mm}$, and mass to the nearest 0.01 or $0.1 \mathrm{~g}$ for masses $<5$ and $>5 \mathrm{~g}$, respectively. Prey items collected from puffins were immediately sealed in plastic sample bags to prevent dehydration (Montevecchi \& Piatt 1987. Hislop et al. 1991) and were measured within $3 \mathrm{~h}$ of collection.

Four measures of percent prey composition of harvests are reported: occurrence, frequency, mass and energy. Percent occurrence, the proportion of billloads containing a specific prey type, usually sums to more than $100 \%$, because birds often carry more than one prey type in a bill-load. Percent frequency, percent mass and percent energy are based on the total prey in all bill-loads

Analyses. Three-way ANOVA was used to test null hypotheses of differences in proportions of prey types among sampling methods, years, and biweekly intervals. Residuals were inspected for normality and homoscedasticity. Proportions were arcsine transformed to meet assumptions for normality. Including sampling method, year, and date in ANOVA models allowed tests of the effect of each variable while controlling for others. ANOVA, including date and year, was also used to compare fish lengths that were estimated in telescopic samples to those that were measured from mist-netted and incidental samples to assess the accuracy of estimation techniques. Interaction terms were included in initial 3-way models and dropped from all final models because none were significant. Tolerance for Type I error was set at $5 \%$ for all tests. Adjusted least square means are given \pm $1 \mathrm{SD}$. 
Table 1. Comparison of fish lengths $(\mathrm{cm})$ measured from mist-netted samples and estimated from telescopic samples on Great Island, Newfoundland, Canada. Means are adjusted from ANOVA of length by technique, year and date

\begin{tabular}{|c|c|c|c|c|c|c|}
\hline \multirow{2}{*}{ Prey type } & \multicolumn{2}{|c|}{ Measured } & \multicolumn{2}{|c|}{ Estimated } & \multirow[t]{2}{*}{$F$} & \multirow[t]{2}{*}{$\mathrm{p}$} \\
\hline & Mean $\pm S D$ & $(\mathrm{~N})$ & Mean $\pm S D$ & $(N)$ & & \\
\hline \multicolumn{7}{|l|}{ Capelin } \\
\hline Immature & $12.6 \pm 1.7$ & $(135)$ & $12.2 \pm 1.9$ & $(967)$ & 2.94 & 0.087 \\
\hline Gravid & $13.8 \pm 1.6$ & (62) & $13.3 \pm 0.9$ & $(43)$ & 2.24 & 0.138 \\
\hline Male & $15.8 \pm 1.5$ & (54) & $15.2 \pm 0.7$ & (39) & 6.04 & 0.016 \\
\hline Sandlance & $16.0 \pm 3.1$ & (79) & $15.5 \pm 2.4$ & (96) & 1.36 & 0.245 \\
\hline Hake & $5.7 \pm 1.5$ & $(80)$ & $6.3 \pm 0.9$ & $(104)$ & 3.72 & 0.056 \\
\hline
\end{tabular}

\section{RESULTS}

\section{Sampling techniques}

Estimated lengths of male capelin in telescopic samples were significantly shorter than measured iengths from mist-netted samples, after differences due to date and year were considered (Table 1). Estimated lengths did not differ significantly from measured lengths for other prey types. Differences between estimated and measured lengths were considered acceptable for all prey types including male capelin, and no adjustments were made. Mean masses per $\mathrm{cm}$ length class of mea- sured prey (Table 2) were assigned to prey from telescopic and unaided visual samples according to estimated lengths.

Results of ANOVA (Table 3) revealed 2 other biases between sampling techniques: gravid capelin constituted a larger proportion of mist-netted than telescopic and unaided visual samples by percent occurrence, frequency, and mass (Tukey: $p_{\mathrm{s}}<0.001$; Fig. 1), and larval capelin and sandlance formed a greater proportion of telescopic than mist-netted samples by percent frequency and mass (Tukey: $p_{s}=0.028$ ). Proportions of larval fish in unaided visual samples were similar to those in telescopic samples (Fig. 1), but post-hoc differ-

Table 2. Mean mass ( $\mathrm{g}$ ) per cm length class of major prey types delivered to Atlantic puffin chicks on Great Island in 1992 and 1993. Measurements rounded to nearest integer to form length classes (e.g. $10 \mathrm{~cm}$ class included measurements from 9.5 to $10.4 \mathrm{~cm}$ ). Sample sizes are given in parentheses

\begin{tabular}{|c|c|c|c|c|c|c|c|c|}
\hline Class (cm) & $\begin{array}{l}\text { Immature } \\
\text { or spent } \\
\text { capelin }\end{array}$ & $\begin{array}{l}\text { Gravid } \\
\text { capelin }\end{array}$ & Male capelin & Sandlance & Hake & $\begin{array}{l}\text { Larval } \\
\text { sandlance } \\
\text { or capelin }\end{array}$ & Cottid & Crustacean \\
\hline 1 & - & - & - & - & - & $0.01(2)$ & - & - \\
\hline 2 & - & - & _- & - & _- & $0.03(32)$ & $0.11(11)$ & $0.13(9)$ \\
\hline 3 & - & - & - & - & $0.2(1)$ & $0.06(93)$ & $0.18(53)$ & $0.15(12)$ \\
\hline 4 & - & - & - & - & $0.5(7)$ & $0.10(52)$ & $0.62(8)$ & $0.25(1)$ \\
\hline 5 & - & - & - & - & $0.7(32)$ & $0.25(69)$ & - & - \\
\hline 6 & - & - & - & $0.3(1)$ & $1.4(14)$ & $0.38(104)$ & - & $0.90(1)$ \\
\hline 7 & $0.8(1)$ & - & - & $0.8(2)$ & 2.1 (17) & $0.92(43)$ & - & - \\
\hline 8 & $1.6(18)$ & - & - & $1.0(2)$ & $3.1(4)$ & $1.42(5)$ & - & - \\
\hline 9 & $2.4(15)$ & - & - & - & $4.5(2)$ & $2.05(2)$ & - & - \\
\hline 10 & $3.6(12)$ & - & - & - & - & - & - & - \\
\hline 11 & $4.6(23)$ & $5.3(4)$ & - & $1.5(1)$ & $9.2(1)$ & - & - & - \\
\hline 12 & $5.5(64)$ & $7.8(17)$ & - & - & $10.6(1)$ & - & - & - \\
\hline 13 & $7.3(62)$ & 9.1 (14) & $11.1(6)$ & $4.8(10)$ & - & - & - & - \\
\hline 14 & $8.6(47)$ & $12.8(10)$ & $13.1(10)$ & $5.9(7)$ & - & - & - & - \\
\hline 15 & $10.5(46)$ & $15.0(6)$ & $16.0(12)$ & $6.9(13)$ & - & - & - & - \\
\hline 16 & $12.7(34)$ & $19.0\{4\}$ & $20.6(10)$ & $9.5(12)$ & - & - & - & - \\
\hline 17 & $14.8(6)$ & $20.7(4)$ & $22.6(9)$ & $10.7(13)$ & - & - & - & - \\
\hline 18 & 14.7 (1) & - & $25.4\{5\}$ & $11.9(6)$ & - & - & - & - \\
\hline 19 & - & - & - & $16.2(6)$ & - & - & - & - \\
\hline 20 & - & - & - & $18.5(1)$ & - & - & - & - \\
\hline 21 & - & - & - & $20.9(1)$ & - & - & - & - \\
\hline 22 & - & - & - & $20.6(2)$ & - & - & - & - \\
\hline 23 & - & - & - & $32.8(1)$ & - & - & - & - \\
\hline
\end{tabular}


Table 3. Results of 3-way ANOVA of proportions of Atlantic puffin prey types by mist-net, telescopic, and unaided visual observation sampling techniques, year and biweekly periods. Proportions were arcsine transformed for analyses

\begin{tabular}{|c|c|c|c|c|c|c|}
\hline & \multicolumn{2}{|c|}{ Sampling technique } & \multicolumn{2}{|c|}{ Year } & \multicolumn{2}{|c|}{ Date } \\
\hline & $F^{*}$ & $\mathrm{p}$ & $F$ & $\mathrm{p}$ & $F$ & $\mathrm{p}$ \\
\hline \multicolumn{7}{|l|}{ Percentage occurrence } \\
\hline Capelin - gravid & 13.47 & 0.00 & 1.89 & 0.17 & 7.55 & 0.00 \\
\hline Capelin - male & 0.56 & 0.58 & 1.51 & 0.23 & 7.27 & 0.00 \\
\hline Capelin - immature or spent & 0.92 & 0.41 & 0.71 & 0.50 & 24.25 & 0.00 \\
\hline Sandlance & 0.17 & 0.85 & 0.58 & 0.57 & 3.15 & 0.04 \\
\hline Larval sandlance and capelin & 0.88 & 0.43 & 1.14 & 0.33 & 38.27 & 0.00 \\
\hline Hake & 0.17 & 0.85 & 2.97 & 0.06 & 9.68 & 0.00 \\
\hline Cottid & 0.48 & $0.49^{\circ}$ & 3.72 & 0.03 & 3.90 & 0.02 \\
\hline Crustacean & 2.53 & 0.09 & 7.30 & 0.00 & 4.21 & 0.01 \\
\hline Other & 2.87 & 0.07 & 6.79 & 0.00 & 0.77 & 0.52 \\
\hline \multicolumn{7}{|l|}{ Percentage frequence } \\
\hline Capelin - gravid & 9.43 & 0.00 & 1.73 & 0.19 & 6.19 & 0.00 \\
\hline Capelin - male & 0.57 & 0.57 & 1.62 & 0.21 & 7.84 & 0.00 \\
\hline Capelin - immature or spent & 1.28 & 0.29 & 0.55 & 0.58 & 42.77 & 0.00 \\
\hline Sandlance & 1.38 & 0.26 & 1.17 & 0.32 & 3.83 & 0.02 \\
\hline Larval sandlance & 3.75 & 0.03 & 5.60 & 0.01 & 46.41 & 0.00 \\
\hline Hake & 0.92 & 0.41 & 4.08 & 0.03 & 4.47 & 0.01 \\
\hline Cottid & 0.77 & $0.39^{\circ}$ & 4.75 & 0.01 & 3.55 & 0.02 \\
\hline Crustacean & 0.09 & 0.92 & 12.97 & 0.00 & 0.29 & 0.84 \\
\hline Other & 3.09 & 0.06 & 4.84 & 0.01 & 0.71 & 0.53 \\
\hline \multicolumn{7}{|l|}{ Percentage mass } \\
\hline Capelin - gravid & 15.13 & 0.00 & 3.29 & 0.05 & 6.65 & 0.00 \\
\hline Capelin - male & 0.41 & 0.67 & 1.35 & 0.27 & 6.99 & 0.00 \\
\hline Capelin - immature or spent & 2.34 & 0.11 & 1.56 & 0.22 & 14.55 & 0.00 \\
\hline Sandlance & 0.00 & 1.00 & 2.24 & 0.12 & 3.52 & 0.02 \\
\hline Larval sandlance and capelin & 3.75 & 0.03 & 3.01 & 0.06 & 25.30 & 0.00 \\
\hline Hake & 0.04 & 0.96 & 2.01 & 0.15 & 9.56 & 0.00 \\
\hline Cottid & 0.75 & $0.40^{\mathrm{d}}$ & 3.16 & 0.05 & 3.99 & 0.02 \\
\hline Crustacean & 0.55 & 0.58 & 7.43 & 0.00 & 7.88 & 0.00 \\
\hline Other & 1.40 & 0.26 & 5.54 & 0.01 & 0.55 & 0.65 \\
\hline
\end{tabular}

ences between mist-netted and unaided visual samples did not attain significance for either percent frequency $(p=0.077$ ) or mass $(p=0.076)$. Differences among sampling techniques in the proportions of gravid capelin were greatest at the beginning of chickfeeding in July and were less in August (Table 4).

Mist-netted samples were considered to provide an accurate measure of the proportion of gravid capelin because all capelin collected were dissected. Thus, the proportions of gravid capelin in telescopic and unaided visual samples were adjusted upwards (with a compensating reduction in proportions identified as immature or spent) by a factor equal to the difference between proportions identified in mist-netted samples and proportions identified in telescopic and unaided visual samples for each biweekly period (Table 4). Small larval fishes are difficult to recover completely following capture of puffins in mist-nets, and proportions of larval fish were probably most accurately determined in telescopic samples. No attempt was made to adjust proportions of larval fish in mist-netted samples because it was not certain that telescopic counts were correct, and because samples from mistnets constituted a minority of total samples and would not create a large bias in overall estimated proportion of prey consumption. Following adjustments to the proportions of gravid capelin, mist-netted, telescopic, and unaided visual observation samples were pooled to describe prey composition. All analyses were performed on unadjusted proportions, controlling for differences due sampling techniques by including it as a variable in ANOVA models.

\section{Composition of prey harvests}

Forage fishes constituted $88 \%$ by frequency and $98 \%$ by mass of all prey items identified in mist-netted 
and telescopic samples in 1992-94 (Table 5). Crustaceans, primarily hyperiid amphipods, squid and polychaete worms made up the remaining invertebrate prey. Capelin and sandlance, in similar proportions, were the most abundant prey. Most sandlance were larval fish, and capelin formed the vast bul.k of prey biomass (Table 5).

\section{Differences by location}

There were no significant differences in the proportions of different prey for samples paired by date on the north and south sides of the island between 17 July and 29 August 1993 (ANOVA: $p>0.1$ for all prey types and measures of abundance). Samples from both locations were pooled in all other analyses.

\section{Changes through the season}

Proportions of all major prey types changed through the nestling period (Table 3, Fig. 2). Trends for most prey types were similar in the 3 years (Fig. 3). Smaller prey, including hake, larval capelin and sandlance, cottids and crustaceans, were most prevalent early in the nestling period (Table 6, Fig. 2). Percentages of gravid capelin tended to be highest in the middle of the nestling period.
Male capelin were more prevalent in early August than during any other biweekly period. Proportions of immature and spent female capelin increased steadily through the nestling period. Sandlance proportions were lowest in early July (Table 6, Fig. 2).

\section{Inter-annual difíerences}

Proportions of gravid capelin were significantly different among years by mass but not by occurrence or frequency (Table 3). The greatest difference indicated higher proportions of heavier fishes in 1993 than 1992 , but results of post-hoc tests were not significant (Tukey: $p=0.075$, but see below). Proportions of other large prey (capelin and sandlance) did not differ significantly across years (Fig. 3).

Smaller prey showed many differences among years (Table 3. Fig. 3). By all abundance measures, crustaceans formed a larger proportion of prey in 1994 than in 1992 and 1993, and the proportion of prey categorized as 'other' was higher in 1994 than 1993 (Tukey: $\left.\mathrm{p}_{\mathrm{s}}<0.05\right)$. By percent frequency, cottids were higher in 1993 than 1992, hake were higher in 1992 than 1993, and I-group (larval) capelin and O-group sandlance were higher in 1992 than 1993 and 1994 (Tukey $p_{s}<$ 0.05). Cottids were also higher in 1993 than 1992 by percent occurrence (Tukey: $p=0.026$ ).

Table 4. Differences in the percentage of capelin (excluding mature males and larval l-group) that were identified as gravid in mist-net, telescopic, and unaided visual samples during biweekly periods in 1992 and 1993

\begin{tabular}{|c|c|c|c|c|c|c|}
\hline & \multicolumn{2}{|c|}{ Mist-net } & \multicolumn{2}{|c|}{ Telescope } & \multicolumn{2}{|c|}{ Unaided visual } \\
\hline & $N^{d}$ & $\begin{array}{l}\text { Percent } \\
\text { gravid }\end{array}$ & $N^{d}$ & $\begin{array}{l}\text { Percent } \\
\text { gravid }\end{array}$ & $N^{a}$ & $\begin{array}{l}\text { Percent } \\
\text { gravid }\end{array}$ \\
\hline \multicolumn{7}{|l|}{ By occurrence } \\
\hline $1-15$ July & 29 & 44.8 & 19 & 0.0 & 171 & 5.2 \\
\hline $16-30 \mathrm{July}$ & 28 & 32.1 & 122 & 13.1 & 384 & 9.6 \\
\hline 31 July-1.4 Aug & 42 & 19.1 & 73 & 20.6 & 721 & 3.6 \\
\hline $15-29 \mathrm{Aug}$ & 43 & 4.7 & 175 & 1.1 & 229 & 0.4 \\
\hline Overall & 143 & 23.1 & 389 & 8.5 & 1506 & 4.9 \\
\hline \multicolumn{7}{|l|}{ By frequency } \\
\hline $1-15$ July & 35 & 45.7 & 30 & 0.0 & 203 & 4.4 \\
\hline $16-30$ July & 32 & 28.1 & 172 & 9.3 & 624 & 6.7 \\
\hline 31 July-14 Aug & 59 & 17.0 & 101 & 14.9 & 1061 & 3.0 \\
\hline $15-29 \mathrm{Aug}$ & 53 & 3.8 & 251 & 0.8 & 334 & 0.3 \\
\hline Overall & 179 & 20.7 & 554 & 6.0 & 2222 & 3.8 \\
\hline \multicolumn{7}{|l|}{ By mass $^{d}$} \\
\hline $1-15$ July & 309 & 59.2 & 1.88 & 0.0 & 1290 & 8.1 \\
\hline $16-30$ July & 340 & 37.2 & 1099 & 16.2 & 3868 & 12.9 \\
\hline 31 July-14 Aug & 467 & 25.9 & 858 & 22.8 & 8832 & 2.4 \\
\hline $15-29$ Aug & 376 & 4.7 & 2147 & 1.3 & 2840 & 0.5 \\
\hline Overall. & 1493 & 30.0 & 4293 & 9.4 & 16829 & 4.9 \\
\hline
\end{tabular}



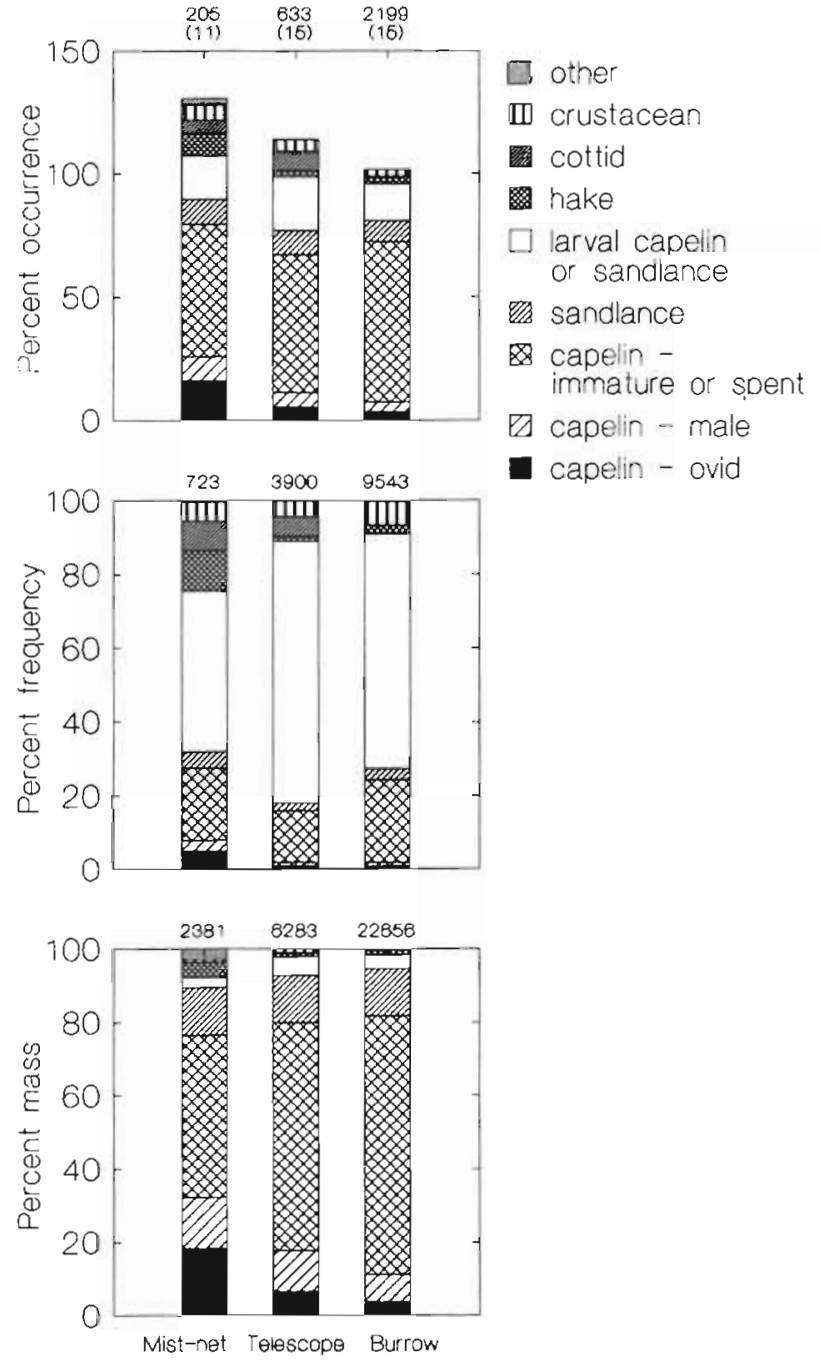

\section{Sampling technique}

Fig. 1 Comparison of mist-netted, telescopic and unaided visual observation methods of sampling prey delivered to Atlantic puffin chicks on Great Island, Newfoundland. Numbers along the tops of the percent occurrence, frequency and mass graphs indicate number of bill-loads (number of sampling sessions in parentheses), number of prey items, and total mass $(g)$ of prey, respectively. Cottids were lumped with

larval capelin and sandlance in unaıded visual records

\section{Size distribution of larger fish prey}

Gravid and male capelin and sandlance delivered to chicks were shorter in 1992 than in 1993 and 1994 (Table 7 ; Tukey: $p_{s}<0.05$ ). Lengths of inmature and spent capelin were greater in 1993 than in 1992 and 1994 (Tukey: $\mathrm{p}_{\mathrm{s}}<0.001$ ), but, unlike gravid and male capelin, were not significantly different between 1992 and 1994 and were shorter in 1994 than 1993 (Tukey: p $<0.001)$. Proportions of immature and spent capelin
Table 5. Overall composition of prey brought to Atlantic puffin chicks on Great lsland as identified from mist-net and telescopic samples in 1992-94

\begin{tabular}{|c|c|c|c|}
\hline Prey type & $\begin{array}{l}\text { Number } \\
\text { identified }\end{array}$ & $\begin{array}{l}\text { Percentage } \\
\text { by frequency }\end{array}$ & $\begin{array}{l}\text { Percentage } \\
\text { by mass }\end{array}$ \\
\hline \multicolumn{4}{|l|}{ Vertebrate species } \\
\hline \multicolumn{4}{|l|}{ Capelin } \\
\hline \multicolumn{4}{|l|}{ Mallotus villosus } \\
\hline Larval $^{d}$ & 1274 & 19.7 & 2.5 \\
\hline $\begin{array}{l}\text { Immature or spent } \\
\text { female }\end{array}$ & 879 & 13.6 & 51.0 \\
\hline Gravid female ${ }^{b}$ & 310 & 4.8 & 20.1 \\
\hline Male & 60 & 0.9 & 9.0 \\
\hline Total capelin & 2523 & 38.9 & 82.6 \\
\hline \multicolumn{4}{|l|}{ Sandlance } \\
\hline \multicolumn{4}{|l|}{ Ammodytes spp. } \\
\hline Larval $^{\dagger}$ & 2475 & 38.2 & 2.3 \\
\hline Adult & 121 & 1.9 & 9.8 \\
\hline Gravid female & 7 & 0.1 & 0.7 \\
\hline Total sandlance & 2603 & 40.2 & 12.8 \\
\hline \multicolumn{4}{|l|}{ Gadid } \\
\hline $\begin{array}{l}\text { Urophycis tenuis } \\
\text { Atlantic cod }\end{array}$ & 182 & 2.8 & 1.9 \\
\hline \multicolumn{4}{|l|}{ Atlantic tomcod } \\
\hline Microgadus tomcod & 1 & $<0.1$ & $<0.1$ \\
\hline $\begin{array}{l}\text { Butterfish } \\
\text { Poronotus triacanthus }\end{array}$ & \multicolumn{2}{|c|}{ Butterfish } & $<0.1$ \\
\hline Cottid ${ }^{r}$ & 423 & 6.5 & 0.6 \\
\hline \multicolumn{4}{|l|}{ Invertebrate species } \\
\hline \multicolumn{2}{|l|}{ Hyperiid } & & \\
\hline - Parathemisto spp. & 709 & 10.9 & 0.9 \\
\hline Gammarid & 3 & $<0.1$ & $<0.1$ \\
\hline \multicolumn{4}{|l|}{ Euphausiid } \\
\hline - Thyanoessa spp. & 28 & $<0.1$ & $<0.1$ \\
\hline Total crustacean & 739 & 11.4 & 1.0 \\
\hline \multicolumn{4}{|l|}{ Squid } \\
\hline \multicolumn{3}{|l|}{ Polychaete } & $<0.1$ \\
\hline Total items & 6482 & 100.0 & 100.0 \\
\hline \multicolumn{4}{|c|}{$\begin{array}{l}\text { "A total of } 3749 \text { larval capelin (I-group) and sandlance (O- } \\
\text { group) were recorded, of which } 309 \text { were identified to } \\
\text { species. Proportions in that sample were used to estimate } \\
\text { overall numbers of each species }\end{array}$} \\
\hline \multicolumn{4}{|c|}{$\begin{array}{l}{ }^{\circ} \text { Number of capelin identified as gravid were adjusted } \\
\text { upwards in telescopic samples (see text) }\end{array}$} \\
\hline \multicolumn{4}{|c|}{$\begin{array}{l}\text { 'Cottid species identified included grubby Myoxoceph- } \\
\text { alus aeneus, shorthorn sculpin } M \text {. scopius and longhorn } \\
\text { sculpin } M \text {. octodecemspinosus }\end{array}$} \\
\hline
\end{tabular}

that were partly scaled were larger in $1994(39 \% ; \mathrm{N}=$ 466) than $1992(17 \% ; \mathrm{N}=280)$ and $1993(6 \% ; \mathrm{N}=596$; $\left.\chi_{2}^{2}=184.1, \mathrm{p}<0.001\right)$. When partly scaled fish are excluded from the immature and spent capelin cate- 

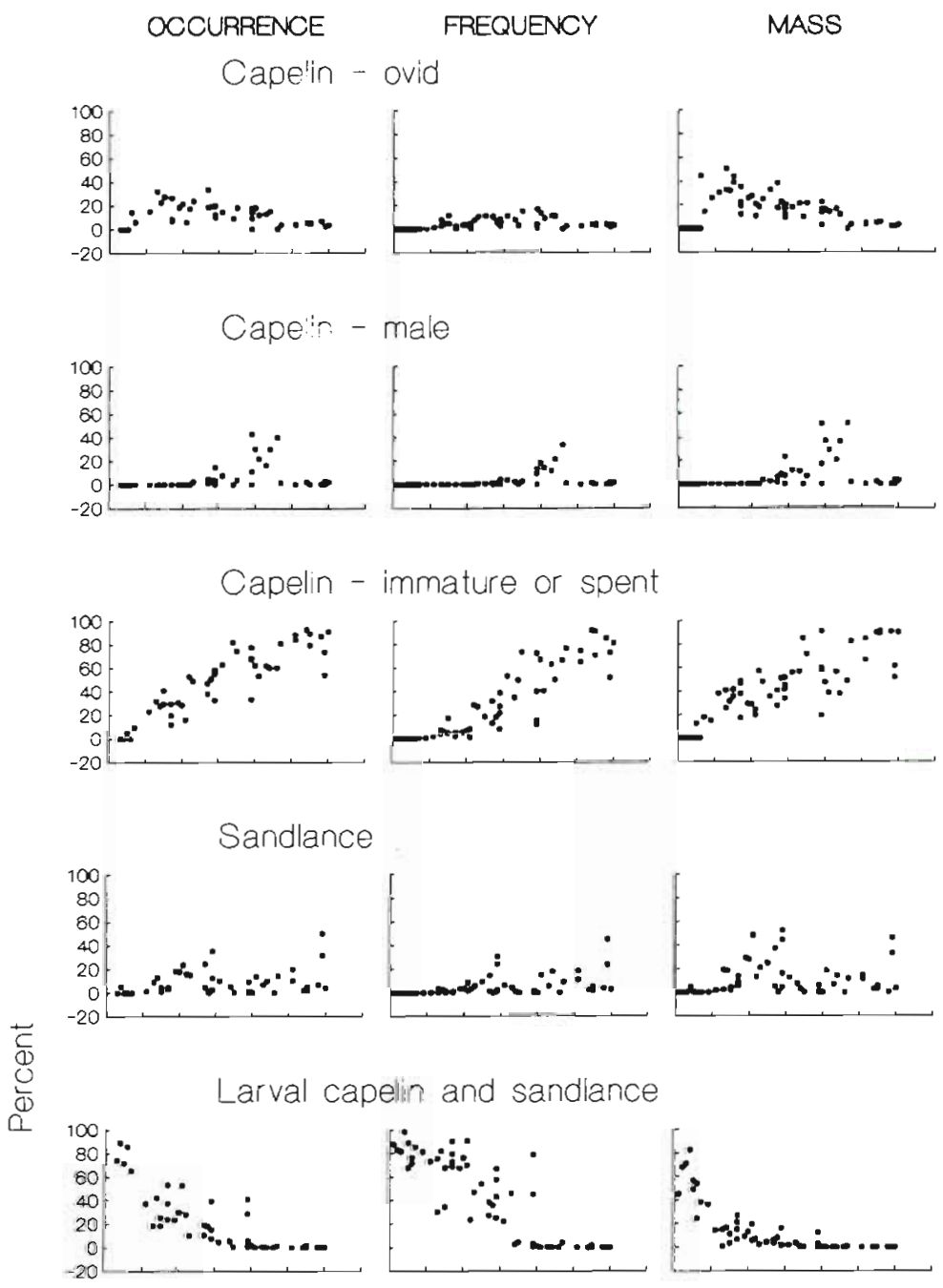

Hake

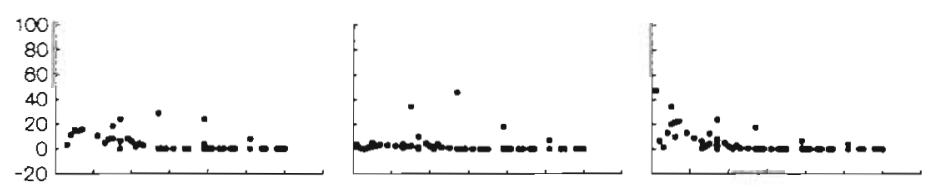

\section{Cottid}
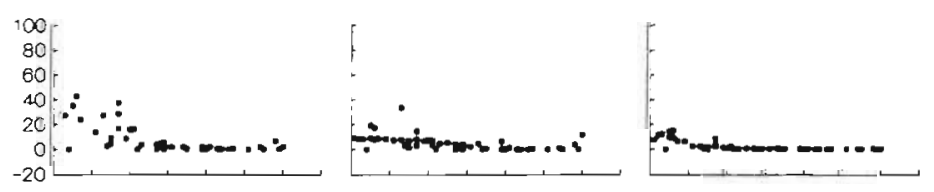

Crustacean

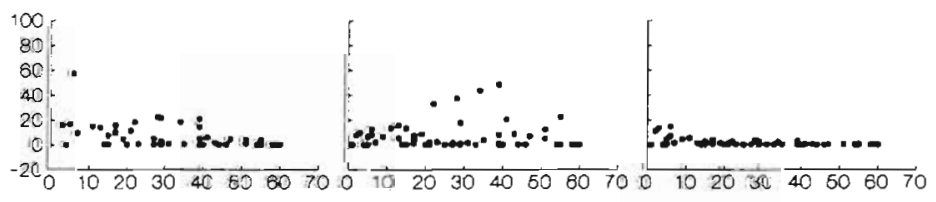

Date (days after 30 June) gory, the pattern of yearly differences in length is similar to those for gravid and male capelin and sandlance (Table 7), with length shorter in 1992 than in 1993 and 1994 (Tukey: $p_{\mathrm{s}}<0.001$ ). However, lengths of spent females and fully scaled immatures were still significantly shorter in 1994 than 1993 (Tukey: $p=0.005$ ). Lengths of partly scaled immature capelin were similar in the 3 years (Table 7 ).

Male capelin $(15.5 \pm 1.2 \mathrm{~cm}, \mathrm{~N}=93)$ were significantly longer than gravid (13.6 \pm $1.4 \mathrm{~cm}, \mathrm{~N}=107$ ) and spent or immature capelin (excluding partly scaled fish: $13.3 \pm$ $1.4 \mathrm{~cm}, \mathrm{~N}=1056$ ) over the 3 years of study $\left(F_{2,1253}=115.2, \mathrm{p}<0.001_{\mathrm{i}}\right.$ Tukey: $\mathrm{p}_{\mathrm{s}}<$ $0.001)$. Gravid capelin were significantly longer than spent or immature capelin (Tukey $p=0.022$ ). Partly scaled, I-group capelin averaged $9.3 \pm 0.9 \mathrm{~cm}(\mathrm{~N}=262)$ and sandlance averaged $15.8 \pm 2.8 \mathrm{~cm}(\mathrm{~N}=$ 180) during 1992-94 (Fig. 4).

Length increased significantly through the season for gravid capelin $\left(F_{3,98}=4.55\right.$, $\mathrm{p}=0.005)$, immature and spent capelin $\left(F_{3,1307}=67.65, \mathrm{p}<0.001\right)$ and hake $\left(F_{3,177}=\right.$ 8.10, p < 0.001), but not for other prey types (Fig. 5). Gravid capelin were longer in early August $(14.2 \pm 1.2 \mathrm{~cm}, \mathrm{~N}=36)$ than in early July $(12.6 \pm 1.3 \mathrm{~cm}, \mathrm{~N}=12)$, immature and spent capelin were longer in early and late August $(12.8 \pm 1.9 \mathrm{~cm}, N=461$ and $13.1 \pm 1.5 \mathrm{~cm}, \mathrm{~N}=393$, respectively) than in early and late July $(12.0 \pm 2.2 \mathrm{~cm}$, $\mathrm{N}=50$ and $11.5 \pm 2.0 \mathrm{~cm}, \mathrm{~N}=410$, respectively) and hake were longer in late August $(7.7 \pm 2.7 \mathrm{~cm}, \mathrm{~N}=7)$ than in all other biweekly periods $(5.3 \pm 0.8 \mathrm{~cm}, \mathrm{~N}=$ $54.5 .7 \pm 1.0 \mathrm{~cm}, \mathrm{~N}=108$ and $5.4 \pm 1.6 \mathrm{~cm}$, $N=15$, for early and late July and early August, respectively; Tukey $p_{s}<0.05$ ). Among larger fish prey, mass at length was highest for hake, greater for male and gravid capelin than for immature and spent capelin, and was lowest for sandlance (Fig. 6)

Fig. 2. Seasonal changes in relative abundance of prey types delivered to Atlantic puffin chicks on Great Island in 1992-94 by percent occurrence, frequency and mass. Each point represents one sampling session 
Table 6. Results of Tukey post-hoc pairwise comparisons of proportions of Atlantic puffin prey types among biweekly date periods. Periods 1, 2, 3 and 4 correspond to 1 to 15 July, 16 to 30 July, 31 July to 14 August, and 15 to 29 August, respectively. Only significant differences are summarized; no significant differences are indicated by a dash. Greater than and less than signs indicate direction of difference between date categories

\begin{tabular}{|c|c|c|c|c|c|c|c|c|c|c|c|c|}
\hline \multirow{2}{*}{ Prey type } & \multicolumn{4}{|c|}{ Percent occurence-_- } & \multicolumn{4}{|c|}{ Percent frequency } & \multicolumn{4}{|c|}{-Percent mass } \\
\hline & 1 & 2 & 3 & 4 & 1 & 2 & 3 & 4 & 1 & 2 & 3 & 4 \\
\hline \multicolumn{13}{|l|}{ Capelin } \\
\hline Gravid & - & $>4$ & $>4$ & $<2,3$ & $<3$ & - & $>1,4$ & $<3$ & - & $>4$ & $>4$ & $<2,3$ \\
\hline Male & $<3$ & $<3$ & $>1,2,4$ & $<3$ & $<3$ & $<3$ & $>1,2,4$ & $<3$ & $<3$ & $<3$ & $>1,2,4$ & $<3$ \\
\hline Immature $^{\mathrm{a}}$ & $<2,3,4$ & $>1 ;<3,4$ & $>1,2$ & $>1,2$ & $<3,4$ & $<3,4$ & $>1,2 ;<4$ & $>1,2,3$ & $<2,3,4$ & $>1:<4$ & $>1$ & $>1,2$ \\
\hline Sandlance & - & - & - & - & $<4$ & - & & $>1$ & $<2$ & $>1$ & - & - \\
\hline Larval $^{b}$ & $>2,3,4$ & $<1_{i}>3,4$ & $<1,2$ & $<1,2$ & $>3,4$ & $>3,4$ & $<1,2 ;>4$ & $<1,2,3$ & $>2,3,4$ & $<1 ;>3,4$ & $<1,2$ & $<1,2$ \\
\hline Hake & $>3,4$ & $>4$ & $<1$ & $<1,2$ & $>4$ & $>4$ & - & $<1,2$ & $>3,4$ & $>4$ & $<1$ & $<1,2$ \\
\hline Cottid & $>3$ & - & $<1$ & - & $>3$ & - & $<1$ & - & $>3.4$ & - & $<1$ & $<1$ \\
\hline Crustacean & $>4$ & - & - & $<1$ & - & - & - & - & $>2,3,4$ & $<1$ & $<1$ & $<1$ \\
\hline
\end{tabular}

\section{Total prey consumed by chicks}

Composition of prey delivered to 32 chicks that fledged and 15 chicks that died in the observation plot over the nestling period in 1993 is shown in Fig. 7. Chicks that fledged received $90 \%$ by frequency $(\mathrm{N}=9730)$ and $91 \%$ by mass ( $N=24399 \mathrm{~g}$ ) of total prey deliveries to burrows during all-day watches. Estimated total number of prey consumed per chick from hatching to fledging averaged 1105 $\pm 435(\mathrm{~N}=32)$ items comprising $2812 \pm 579 \mathrm{~g}$ and $12506 \pm 2391 \mathrm{~kJ}$ (Table 8 ). Proportions of major prey types in overall diet estimated from unaided visual observations in 1993 (Table 8) were similar to proportions calculated from mist-netted and telescopic samples in 1992-94 (Table 5).

\section{DISCUSSION}

\section{Sampling techniques}

Major disadvantages of collecting dietary data from marine birds are associated with the death, injury and disturbance of birds from which food is sampled. Many studies involve the collection of birds at sea (e.g. Schneider \& Hunt 1984), while other studies at breeding colonies involve stomach-pumping adults that

Fig. 3. Composition of prey delivered to Atlantic puffin chicks on Great Island during biweekly periods in 1992, 1993 and 1994. See legend and explanation of numbers in Fig. 1
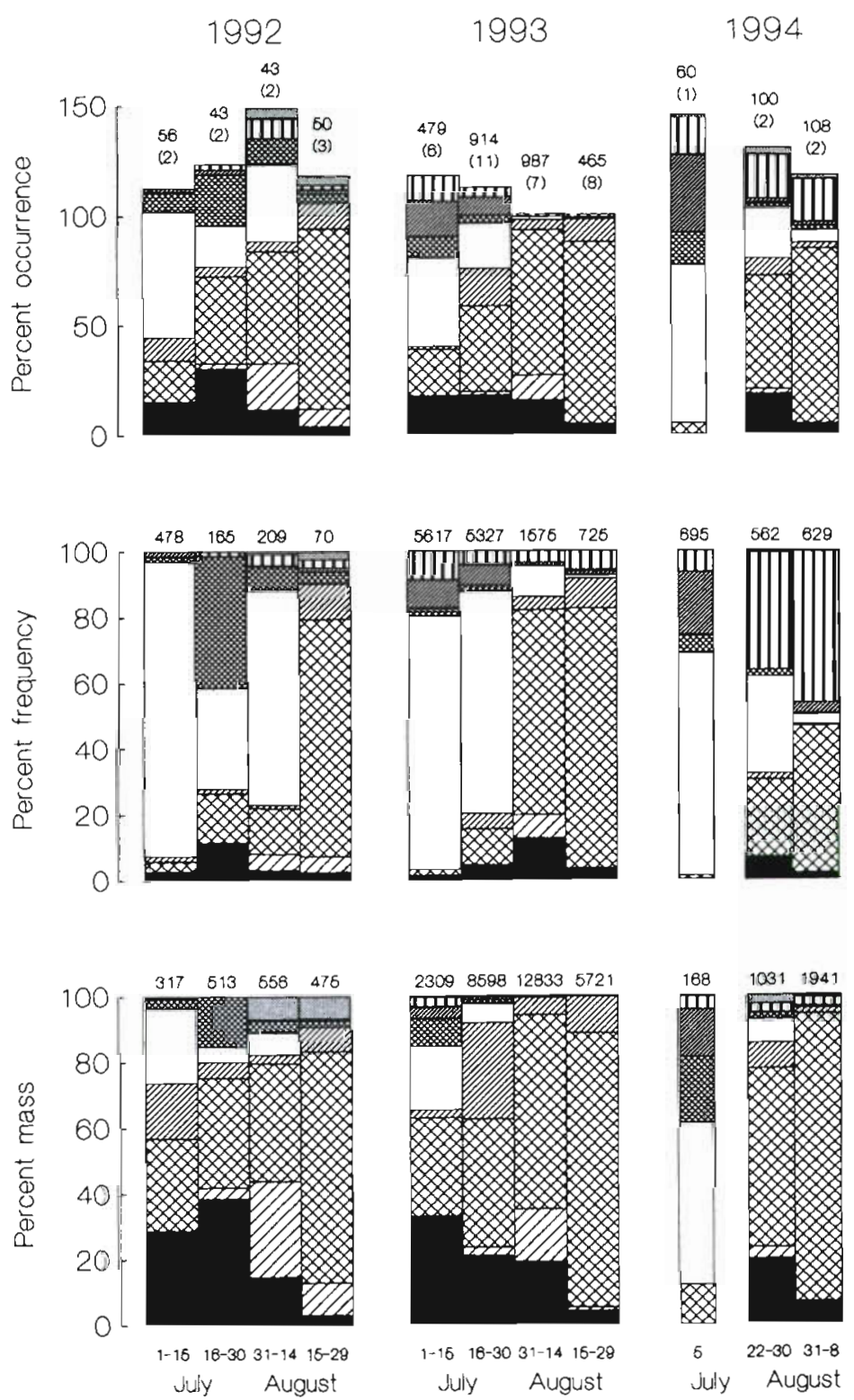
Table 7. Comparison of mean ( \pm SD) fish lengths $(\mathrm{cm}$ ) in 1992, 1993 and 1994; sample sizes are given in parentheses. Means are adjusted from ANOVA of length by technique (measured or estimated), year and date

\begin{tabular}{|c|c|c|c|c|c|c|c|c|}
\hline Prey type & \multicolumn{2}{|c|}{1992} & \multicolumn{2}{|c|}{1993} & \multicolumn{2}{|c|}{1994} & $F$ & $\mathrm{p}$ \\
\hline \multicolumn{9}{|l|}{ Capelin } \\
\hline Immature & $12.1 \pm 2.0$ & (257) & $13.3 \pm 1.6$ & (591) & $11.7 \pm 2.1$ & $(466)$ & 91.38 & 0.000 \\
\hline Partly scaled & $9.1 \pm 0.9$ & $(46)$ & $9.3 \pm 1.0$ & 1331 & $9.1 \pm 0.9$ & $(182)$ & 0.43 & 0.652 \\
\hline Spent" & $12.6 \pm 1.3$ & $(211)$ & $13.8 \pm 1.3$ & $(558)$ & $13.4 \pm 1.4$ & (284) & 38.28 & 0.000 \\
\hline Gravid & $12.7 \pm 1.5$ & $(37)$ & $13.9 \pm 1.2$ & $(54)$ & $14.0 \pm 1.1$ & (14) & 6.53 & 0.002 \\
\hline Male & $14.4 \pm 1.3$ & (29) & $16.1 \pm 0.9$ & (60) & $16.0 \pm 1.4$ & (4) & 16.45 & 0.000 \\
\hline Sandlance & $14.0 \pm 3.5$ & (50) & $17.0 \pm 1.9$ & $(109)$ & $16.3 \pm 2.6$ & (16) & 17.90 & 0.000 \\
\hline Hake & $6.3 \pm 1.5$ & (83) & $6.0 \pm 0.9$ & $(48)$ & $5.7 \pm 0.9$ & (53) & 1.55 & 0.215 \\
\hline
\end{tabular}

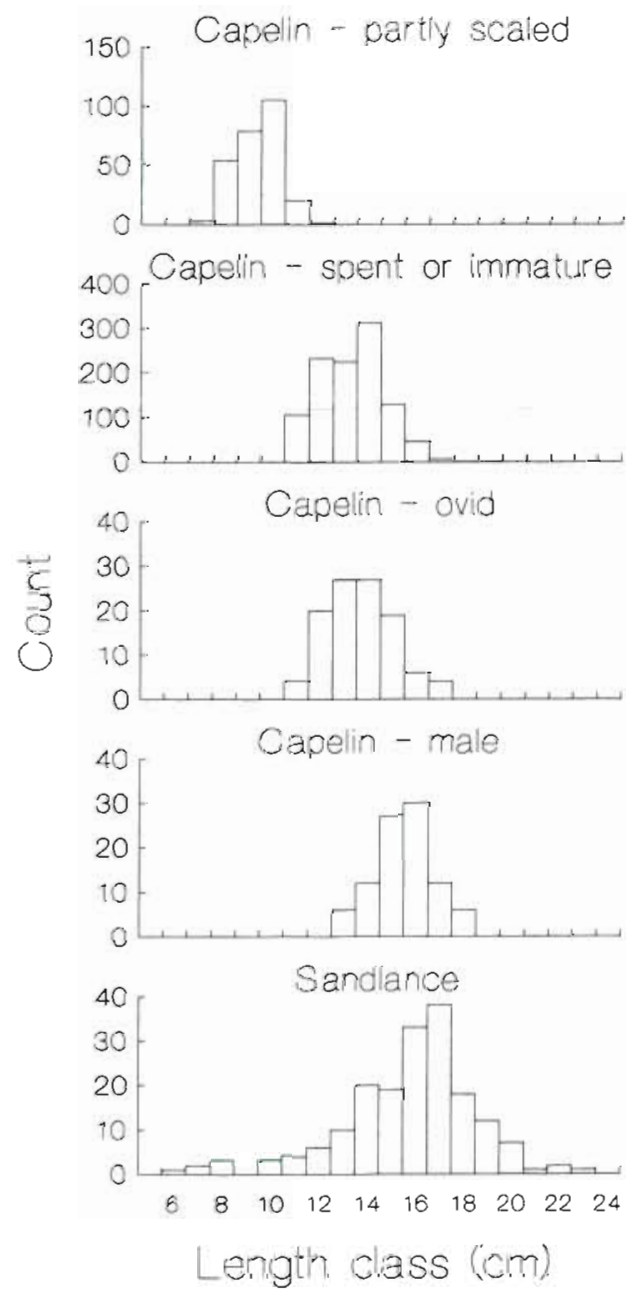

Fig. 4. Length distribution of larger fishes delivered to Atlantic puffin chicks on Great Island in 1992-94. Prey from mist-netted and telescopic samples and from loads dropped by puffins and recovered incidentally are included

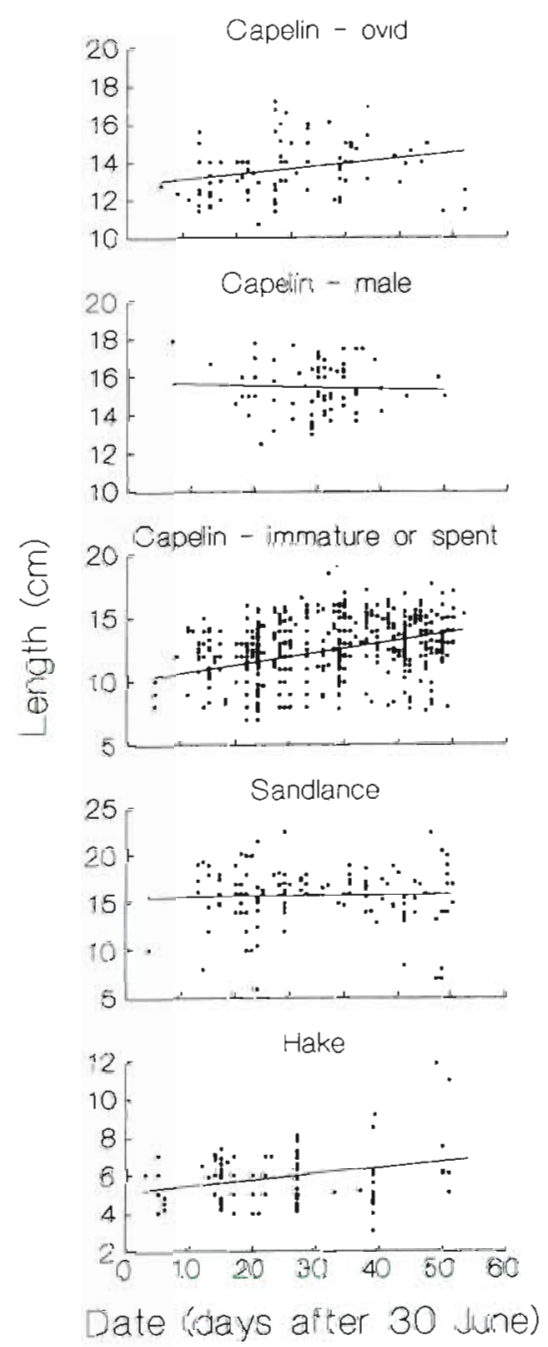

Fig. 5. Seasonal changes in length of larger fishes delivered to Atlantic puffin chicks on Great Island in 1992-94. Prey from mist-netted and telescopic samples and from loads dropped by puffins and recovered incidentally are included. Leastsquares linear regression lines are fit to the data for descriptive purposes 


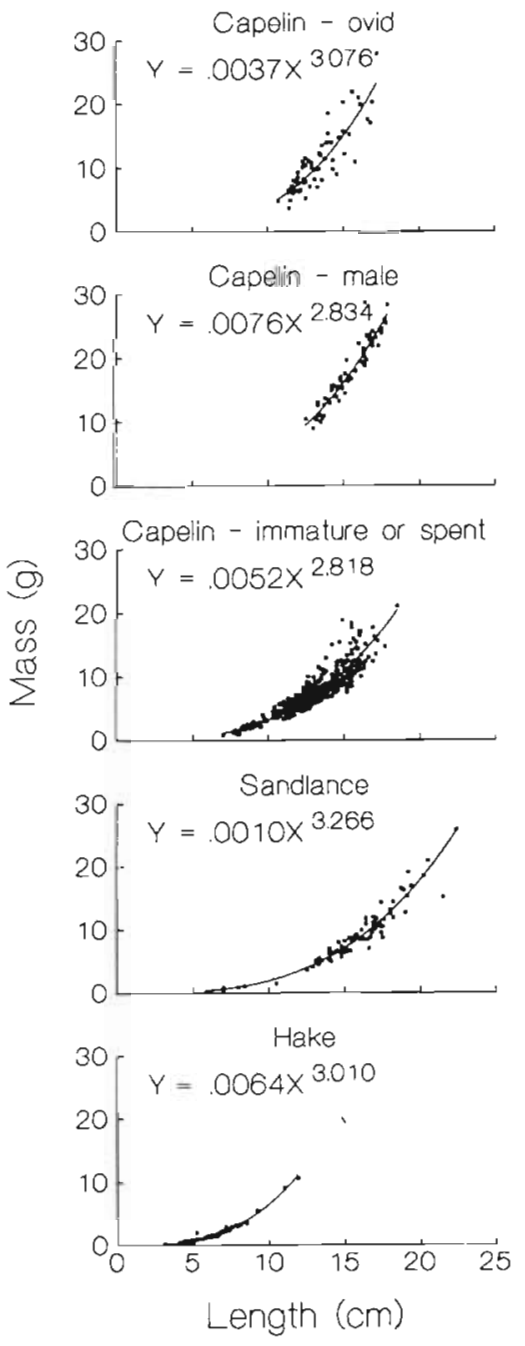

Fig. 6. Mass-length relationships for larger fishes delivered to Atlantic puffin chicks on Great Island in 1992-94

regurgitate food to chicks (e.g. Wilson 1984), actively chasing (Nettleship 1991) or mist-netting (Barrett et al. 1987) food-laden parents delivering food to chicks, or directly (Berruti \& Colclough 1987) or indirectly (Montevecchi \& Myers 1995a) inducing birds to regurgitate. The least interventive and least disturbing ways to collect dietary data from birds involve the direct observation of prey carried in the beak to mates (Nisbet 1973 , Monaghan et al. 1989) or offspring (e.g. Harris \& Wanless 1985). These observational techniques involve identification of partially visible prey items at a distance and visual estimation of prey length relative to bill length (e.g. Harris \& Wanless 1985), and they can be enhanced with the use of mass and length scales that do not interfere with parental birds.

Our findings affirm that systematic telescopic and unaided visual observations of prey delivered by parental puffins to the breeding colony are reliable,
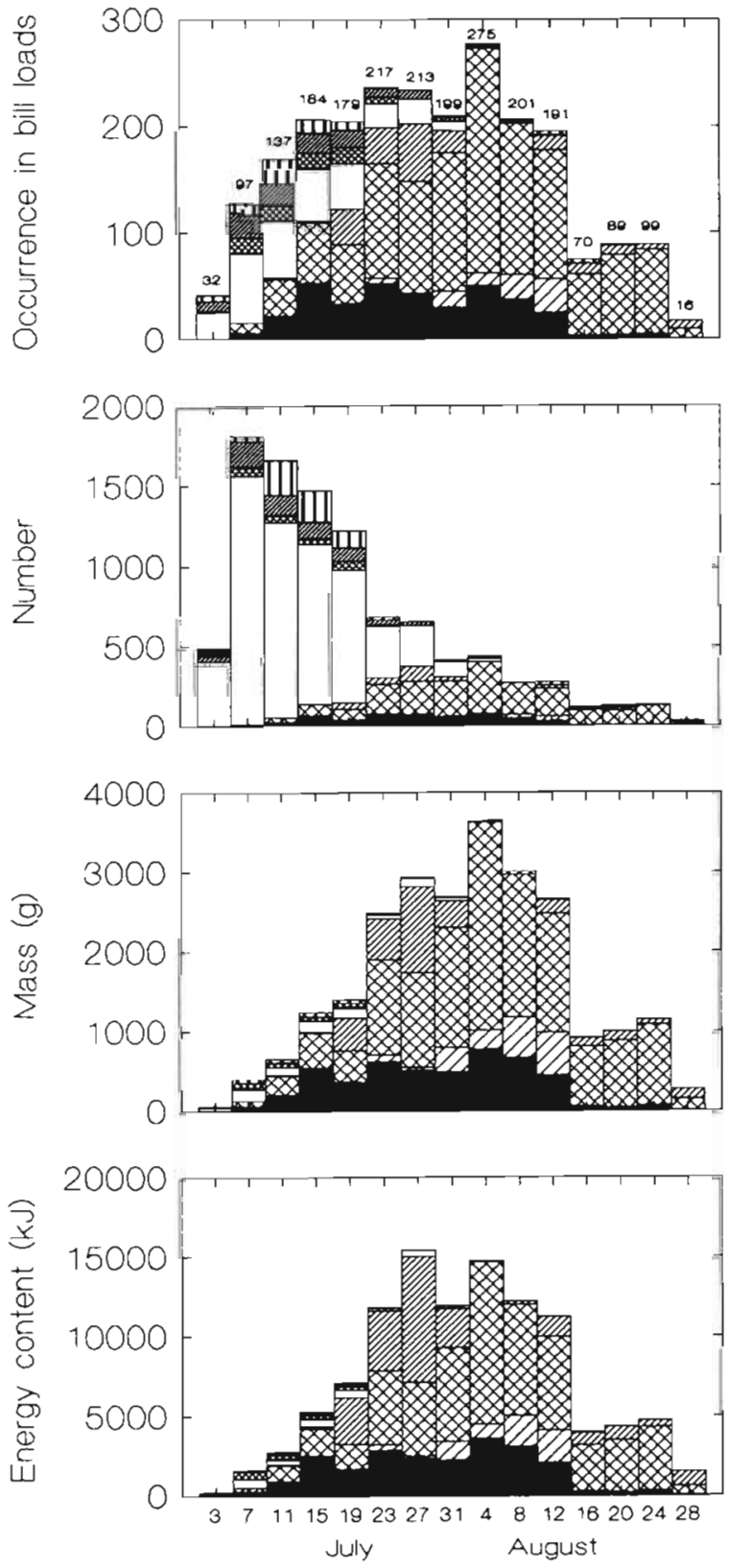

Fig. 7 Total prey delivered every $4 \mathrm{~d}$ throughout the nestling period to Atlantic puffin chicks on Great Island. Total prey includes all food delivered to 32 chicks that fledged and 15 that died. Numbers above bars in top: numbers of bill-loads recorded. For key to prey types, see Fig. 1

noninvasive and relatively nondisturbing techniques for dietary sampling When these observational techniques are combined with mist-netting, corrections can be made for estimates of prey length and of proportions of prey conditions (e.g. gravid, spent). Mass/ length relationships can also be generated from mistnetted samples and used to estimate the masses of parental prey loads. Moreover, our findings suggest that telescopic techniques may be superior to direct 
Table 8. Total average amount of prey consumed by an Atlantic puffin chick from hatching until fledging based on the prey delivered during all-day watches every $4 \mathrm{~d}$ throughout the nestling period to a sample of 32 chicks that fledged from Great Island in 1993. See text for estimation procedure

\begin{tabular}{|c|c|c|c|c|c|c|c|}
\hline \multirow[t]{2}{*}{ Prey type } & \multirow[t]{2}{*}{ Number } & \multirow[t]{2}{*}{$(\%)$} & \multicolumn{2}{|c|}{ Mass } & \multirow{2}{*}{$\begin{array}{l}\text { Energy density } \\
\left(\mathrm{kJ} \mathrm{g}^{-1} \text { wet wt }\right)\end{array}$} & \multicolumn{2}{|c|}{ Energy } \\
\hline & & & g & $(\%)$ & & $\mathrm{kJ}$ & $(\%)$ \\
\hline \multicolumn{8}{|l|}{ Capelin } \\
\hline Larval & 217 & $(19.6)$ & 45.0 & $(1.6)$ & 3.5 & 157.5 & (1.3) \\
\hline Immature or spent female & 206 & $(18.6)$ & 1548.1 & $(55.0)$ & 3.9 & 6037.6 & (48.3) \\
\hline Gravid female & 54 & $(4.9)$ & 588.3 & $(20.9)$ & 4.6 & 2706.2 & $(21.6)$ \\
\hline Male & 10 & $(0.9)$ & 197.0 & $(7.0)$ & 3.8 & 748.6 & $(6.0)$ \\
\hline Total capelin & 487 & $(44.0)$ & 2378.4 & $(84.5)$ & & 9649.9 & $(77.2)$ \\
\hline \multicolumn{8}{|l|}{ Sandlance } \\
\hline Larval & 421 & $(38.1)$ & 39.4 & $(1.4)$ & 3.5 & 137.9 & (1.1) \\
\hline Adult & 31 & $(2.8)$ & 337.8 & $(12.0)$ & 7.3 & 2465.9 & $(19.7)$ \\
\hline Total sandlance & 452 & $(40.9)$ & 377.2 & $(13.4)$ & & 2603.8 & $(20.8)$ \\
\hline White hake & 24 & $(2.2)$ & 31.0 & $(1.1)$ & 5.0 & 155.0 & (1.2) \\
\hline Cottid & 65 & $(5.9)$ & 14.1 & $(0.5)$ & 3.5 & 49.4 & $(0.4)$ \\
\hline Crustacean & 76 & $(6.9)$ & 11.3 & $(0.4)$ & 4.2 & 47.5 & $(0.4)$ \\
\hline Other & $<1$ & $(<0.1)$ & 0.1 & $(<0.1)$ & 4.0 & 0.4 & $\{<0.1\}$ \\
\hline Total & 1105 & $(100)$ & 2812.1 & $(100)$ & & 12506.0 & $(100)$ \\
\hline
\end{tabular}

intervention techniques, such as mist-netting, in the detection of larval (i.e. $O$ and I-group fishes). This result was somewhat surprising, although we were well aware that the 'scattering' of samples from mistnetted birds often resulted in Iarval fishes being 'lost' in the grass. Where possible, we recommend the use of observational techniques for sampling the prey harvests of seabirds. Colony topography, however, influences the utility of different food-sampling techniques. On Great Island, where our study was carried out, puffins nest on grassy areas above steep cliffs, and it was convenient to induce them to congregate along the cliff edge when an observer sat in the vicinity of their burrows. In other colonies in Newfoundland, puffins nest on level habitat (e.g. Small Island) and on gradually sloping habitat (e.g. Baccalieu Island), and telescopic techniques are much less amenable for use (J. Russell pers. comm.). Laying fine meshed capelin nets over burrow entrances (see also Hatch \& Sanger 1992) is useful in some instances for collecting complete loads of prey (W.A.M. \& J Russell unpubl. data).

\section{Prey harvest}

Capelin are a major food for the chicks of most seabird species in eastern Canada (Birkhead \& Nettleship 1987. Cairns et al. 1990a, b, Nettleship 1991, Montevecchi \& Myers 1995a, b). Common murres Uria aalge harvest the most capelin of any seabird species (Cairns et al. 1990b) and feed mostly 3- to 5-yr-old gravid females to chicks (Piatt 1987, W.A.M. unpubl. data). Overall, 2-yr-old capelin made up about $85 \%$ of the food mass delivered to puffin chicks. More than $50 \%$ of the mass of prey consisted of immature and spent female capelin, whereas $20 \%$ was gravid and $9 \%$ male capelin. More than $90 \%$ of capelin delivered to puffin chicks in 1967-69 and in 1982-84 was female (Nettleship 1991). Of female/immature capelin delivered to puffin chicks on Great Island in 1992-94, 26\% were gravid, a proportion that did not differ among years. In comparison, $33 \%$ of the female capelin delivered to puffin chicks on Great Island in 1967-69 were gravid, whereas $14 \%$ were gravid in 1982-84 (Nettleship 1991). However, comparisons of the numbers of samples collected in July and in August/September (Nettleship 1991) indicate significantly later collections in the 1980 s compared to the $1960 \mathrm{~s}\left(\chi^{2}{ }_{1}=20.84, \mathrm{p}<\right.$ 0.001 ), which would bias sampling in the 1980 s to $a$ lower proportion of gravid females. Gravid capelin have significantly higher energy densities than other capelin, whereas large males have the most energy per prey item (Montevecchi \& Piatt 1984). Inshore schools of female capelin tend to occur higher in the water column than schools of males (Templeman 1948), and Erikstad \& Vader (1989) speculated that female capelin may be more accessible to pursuit-diving auks. However, male capelin are also accessible to diving auks, and female capelin, particularly gravid ones, may sim- 
ply be easier for puffins to capture than are larger, more muscular males (Montevecchi \& Myers 1995b).

Larval capelin and sandlance formed the majority of prey during 1992-94. Larval fish were not previously reported in the diet of puffin chicks on Great Island (Nettleship 1991) but they can be common at other colonies (Harris 1984, Barrett et al. 1987), at times associated with breeding failure (Anker-Nilssen 1992). Invertebrate prey for puffin chicks have also been associated with poor feeding conditions (Harris 1984) and breeding failure (Nettleship 1991). In this study, especially in 1994, large numbers of crustaceans were brought to chicks even when alternate, higher energy value foods were apparently available and breeding success was normal (Rodway et al. 1996a). Interannual fluctuations in diet such as these emphasize the necessity for long-term studies to better understand the complexities of dynamic marine food webs.

The lengths of capelin (2-yr-old) delivered to puffin chicks on Great Island in 1992-94 are similar to those delivered to chicks in 1982-84 though shorter than those delivered in the late 1960s (Nettleship 1991). Nettleship (1991) contended that the shorter capelin landed by puffins in 1982-84 compared to 1967-69 were indicative of a change in the age structure of the inshore-spawning capelin population following a large commercial fishery for capelin in the northwest Atlantic in the late 1970s. Smaller capelin in the 1990s could possibly be due to inshore fishing activity and to decreases in length at age attributable to recent cold water events in the northwest Atlantic (Montevecchi \& Myers 1995a, Nakashima 1996).

Male, gravid (2-yr-old) and immature (excluding partially scaled fish) or spent capelin delivered to puffin chicks on Great Island were significantly shorter during 1992 than during 1993 or 1994 . This same general variation in size trends also held for 3- to 5-yr-old capelin delivered to murre chicks on Funk Island during these same years (W.A.M. unpubl. data). Lengths of I-group (partially scaled) capelin were similar in all years, and I-group capelin were proportionally more abundant in chick diets in 1994 than in 1992 or in 1993.

Smaller prey species were more common early in the nestling period, and most gravid capelin were delivered to chicks midway through the nestling period. Many studies have documented increases in prey size with chick age/size (e.g. Hawksley 1957). The delivery of lipid-rich gravid capelin seemingly corresponded with the period of most rapid mass-gain by chicks. However, arrival of capelin in inshore waters was delayed in 1992-94 (Nakashima 1996), and they were not available to earliest hatching chicks (Rodway 1994). As expected, the proportions of spent and immature capelin tended to increase through the season, as did the proportion of sandlance. The mass/ length relationship for sandlance was much lower than that reported by Harris \& Hislop (1978), a difference too great to be attributable to dehydration (Montevecchi \& Piatt 1987). Hence, Hislop et al.'s (1991) formula for energy content by length of sandlance was inappropriate for use with sandlance collected from puffins on Great Island. Within-season changes in the amount and types of prey indicate that prey must be sampled throughout nestling periods to provide unbiased estimates of the relative importance of various prey types.

Our estimate of $2812 \mathrm{~g}$ of food delivered to a chick during the nestling period is about $20 \%$ higher than Brown \& Nettleship's (1984) estimate of $2340 \mathrm{~g}$ per chick (based on $52 \mathrm{~g} \mathrm{~d}^{-1}$ for $45 \mathrm{~d}$; cf. Nettleship 1972). Consumption by captive chicks was estimated to be $82 \mathrm{~g} \mathrm{~d}^{-1}$ or $3659 \mathrm{~g}$ during the nestling period in the northeastern Atlantic (Harris \& Hislop 1978).

In Table 9, we estimate that about $260 \mathrm{t}$ (about $10 \times$ $10^{7}$ individuals) of forage fishes are delivered to Atlantic puffin chicks on Great Island during the breeding season. On the basis of population energetics modelling for marine birds in eastern Canada (Cairns et al. 1990b), it has been estimated that consumption by Atlantic puffin chicks represents only about $6 \%$ of the prey consumed by Atlantic puffins during a reproductive season. Extrapolation to total consumption by Atlantic puffins on Great Island during a breeding season yields an estimate of $4550 \mathrm{t}$ of forage fishes (equivalent to $21 \times 10^{9} \mathrm{~kJ}$ ). Brown \& Nettleship (1984) estimated that in the Witless Bay Ecological Reserve (Great, Pee Pee, Green and Gull Islands) in eastern Newfoundland, the site of the largest breeding concentration of Atlantic puffins in the northwest Atlantic, puffins ate $3891 \mathrm{t}$ of capelin during a $45 \mathrm{~d}$ period (1 July to 15 August). This value represents about $75 \%$ of a similar estimate (5102 t) extrapolated from data in the present study. Current population estimates (Rodway et al. 1996b, W.A.M. unpubl. data) indicate that the puffin colony on Great Island comprises about $41 \%$ of the population in Newfoundland, where overall consumption of forage fishes (mostly 2-yr-old female

Table 9. Estimates of the annual total numbers, mass and energy content of prey delivered to Atlantic puffin chicks on Great Island. Annual fledging production was 84000 chicks based on 1992-93 population estimate of 123000 pairs (Rodway et al. 1996b) and on 1993 breeding success of $68 \%$ (Rodway et al. 1996a); the approximate $30 \%$ of chicks that died before fledging accounted for about $10 \%$ of the prey consumption

\begin{tabular}{|lrrc|}
\hline Delivered to & No. & Mass (t) & KJ \\
\hline Fledged chicks & $9.3 \times 10^{7}$ & 236.2 & $1.1 \times 10^{9}$ \\
Failed chicks & $0.9 \times 10^{7}$ & 21.3 & $0.1 \times 10^{9}$ \\
Total & $10.2 \times 10^{7}$ & 257.5 & $1.2 \times 10^{9}$ \\
\hline
\end{tabular}


capelin) by Atlantic puffins would be in the order of $12400 \mathrm{t}$ during the breeding season. By comparison, common murres may consume about $75 \%$ of this amount of 3- to 5-yr-old capelin (mostly gravid females for chicks) in the Witless Bay area alone (Cairns et al. 1990b). Information on disproportionate consumption of different ages and genders of fishes by seabirds will provide important inputs into trophic and energetics models (see Barrett et al. 1994).

Acknowledgements. Heidi Regehr was instrumental in the field work. Ram Myers, Don Steele, Ian Stenhouse and Carolyn Walsh provided valuable input and information during manuscript preparation by Donna Butler Research was supported by the Department of Biology, Memorial University of Newfoundland, the Canadian Wildlife Service, and by a DFO/NSERC Subvention and an NSERC Individual Operating Grant to W.A.M. We are grateful to the Newfoundland and Labrador Parks Division (Glen Ryan, Douglas Ballam) of the Department of Natural Resources for permission to work on Gieat Island in the Witless Bay Ecolngiral Seabird Reserve.

\section{LITERATURE CITED}

Anker-Nilssen T (1992) Food supply as a determinant of reproduction and population development in Norweglan puffins Fratercula arctica. DSc Thesis, University of Trondheim

Barrett RT, Anker-Nilssen T, Rikardsen F, Valde K, Rov N Vader $W$ (1987) The food, growth and fledging success of Norwegian puffin chicks Fratercula arctica. Ornis Scand 18:73-83

Barrett RT, Becker PH, Furness RW, Hunt GL Jr. Latrouite D, Montevecchi WA, Olsen B, Skøv H, Tasker ML, Wright P (1994) Seabird prey harvests in the North Sea. Seaburd/ Fisheries Interaction Study Group Rep ICES (Copenhagen) CM 1994/L:3

Barrett RT, Røv N, Loen J, Montevecchi WA (1990) Diets of shags Phalacrocorax aristotelis and cormorants $P$. carbo in Norway and implications for gadoid stock recruitment. Mar Ecol Prog Ser 66:205-218

Berruti A, Colclough J (1987) Comparison of the abundance of pilchard in cape gannet diet and commercial catches off the Western Cape South Africa. S Afr J Mar Sci 51 $863-869$

Bertram DF, Kaiser GW (1993) Rhinocerus auklets (Cerorhina monoceratal nestling diet may gauge Pacific sand lance (Ammodytes hexapterus) recruitment. Can J Fish Aquat Sci 50:908-1915

Birkhead TR, Nettleship DN (1987) Ecological relatıonships between common murres, Uria aalge, and thick-bılled murres, Uria lomvia, at the Gannet Islands, Labrador. III. Feeding ecology of young. Can J Zool 65:1638-1645

Bost CA, Koubbi P, Genevois F, Ruchon L, Ridoux V (1994) Gentoo penguin Pygoscels papua diet as an indicator of plankton availability in the Kerguelen Islands. Polar Biol $14: 147-153$

Brown RGB, Nettleship DN (1984) Capelin and seabirds in the northwest Atlantic. In: Nettleship DN, Sanger GA, Springer PF (eds) Marine birds: their feeding ecology and commercial fisheries relationships. Canadian Wildlife Service, Ottawa, p 184-195

Cairns DK (1987) Seabirds as indicators of marine food supplies. Bıol Oceanogr 5:261-271
Caims DK, Chapdelaine G, Montevecchi WA (1990a) Prey harvest by seabirds in the Gulf of St. Lawrence. In: Therriault JC (ed) The Gulf of St. Lawrence: small ocean or large estuary? Can Spec Publ Fish Aquat Scl 113: $277-291$

Caims DK, Montevecchi WA, Birt VL, Macko SA (1990b) Energy expenditures, activity budgets, and prey harvest of breeding common murres. Stud Avıan Biol 14:84-92

Carscadden JE (1984) Capelin in the northwest Atlantic. In Nettleshup DN, Sanger GA, Springer PF (eds) Marine birds: their feeding ecology and commercial fisheries relationships. Canadian Wildlife Service, Ottawa, p 184-195

Croxall JP (1989) Use of indices of predator status and performance in CCAMLR fishery management strategies. Sci Comm Conserv Antarc Mar Liv Resources Pap 1989: $353-365$

Dalley EL, Winters GH (1987) Early life history of sandlance (Ammodytes), with evidence for spawning of A. dubius in Fortune Bay, Newfoundland. Fish Bull US 85:631-641

Erikstad KE, Vader W (1989) Capelin selection by common and Brunnich's guillemots during the prelaying season. Ornis Scand 20:151-155

Furness RW, Cooper J (1982) Interactions between breeding seabird and pelagic fish populations in the southern Benguela region. Mar Ecol Prog Ser 8:243-250

Harris MP (1984) The puffin. Poyser, London

Harris MP, Hislop JRG (1978) The food of young puffins. J Zool 185:213-236

Harris MP, Wanless S (1985) Fish fed to young guillemots, Uria aalge, and used in displays on the Isle of May, Scotland. J Zool Lond 207:441-458

Hatch SA, Sanger GA (1992) Puffins as predators on juvenile pollack and other forage fish in the Gulf of Alaska. Mar Ecol Prog Ser 80:1-1.4

Hawksley O (1957) Ecology of a breeding populatıon of arctic terns. Bird-Banding 28:57-92

Hislop JRG, Harris MP (1985) Recent changes in the food of young puffins Fratercula arctica on the Isle of May in relation to fish stocks. Ib1s 127:234--239

Hislop JRG, Harris MP, Smith JGM (1991) Variation in the calorific value and total energy content of the lesser sandeel (Ammodytes marinus) and other fish preyed on by seabirds. J Zool Lond 224:501-517

Jangaard PM (1974) The capelin (Mallotus villosus): biology distribution, exploitation utilisation, abundance. Bull Fish Res Bd Can 186

Liem AH, Scott WB (1966) Fishes of the Atlantic Coast of Canada. Fisheries Research Board of Canada, Ottawa

Methven DA (1985) Identification and development of larval and juvenile Urophycis chuss, U. tenuis and Phycis chesteri (Pisces, Gadidae) from the northwest Atlantic. J Northw Atl Fish Sci 6:9-20

Monaghan P, Uttley JD, Okill JD (1989) Terns and sandeels: seabirds as indicators of change in marine fish populations. J Fish Biol 35:339-340

Montevecchi WA (1993) Birds as indicators of change in marine prey stocks. In: Furness RW, Greenwood JD (eds) Birds as monitors of environmental change. Chapman and Hall, London, p 217-266

Montevecchi WA, Carns DK, Birt VL (1988) Migration of post-smolt Atlantic salmon, Salmo salar, as inferred by tag recoveries in a seabird colony. Can J Fish Aquat Sci 45 : $568-571$

Montevecchi WA, Myers RA (1995a) Dietary changes of seabirds reflect shifts in pelagic food webs. Sarsia 80 : $313-322$

Montevecchi WA, Myers RA (1995b) Prey harvests of seabirds 
reflect pelagic fish and squid abundance on multiple spatial and temporal scales. Mar Ecol Prog Ser 117:1-9

Montevecchi WA, Piatt JF (1984) Composition and energy contents of mature inshore spawning capelin (Mallotus villosus): implications for seabird predators. Comp Biochem Physiol 67A:15-20

Montevecchi WA, Piatt JF (1987) Dehydration effects on the energy determinations of seabird prey. Can J Zool 65 2822-2824

Montevecchi WA, Ricklefs RE, Kirkham IR, Gabaldon D (1984) Growth energetics of nestling northern gannets. Auk 101:334-341

Nakashima BS (1996) The relationship between oceanographic conditions in the 1990 s and changes in spawning behaviour, growth and early life history of capelin (Mallotus villosus). NAFO Sci Coun Stud 24:55-68

Nettleship DN (1972) Breeding success of the common puffin (Fratercula arctica L.) on different habitats at Great Island, Newfoundland. Ecol Monogr 42:239-268

Nettleship DN (1991) The diet of Atlantic puffin chicks in Newfoundland before and after an international capelin fishery, 1967-1984. Acta 20 Congr Internat Ornithol 20 $2263-2271$

Nisbet ICT (1973) Courtship feeding, egg size and breeding success in common terns. Nature 241:141-143

Piatt JF (1987) Behavioural ecology of common murre and Atlantic puffin predation on capelin: implications for population biology. PhD thesis, Memorial University of Newfoundland, St. John's

Piatt JF, Nettleship DN (1985) Diving depths of four alcids. Auk 102:293-297

This article was submitted to the editor
Pitt TK (1958) Age and growth of the capelin, Mallotus villosus (Müller) in the of fshore Newfoundland area. J Fish Res Bd Can 15:295-311

Regher HM (1994) Breeding performance of black-legged kittiwakes on Great lsland, Newfoundland during periods of reduced food availability. MSc thesis, Memorial University of Newfoundland, St. John's

Rodway MS (1994) Intra-colony variation in breeding success of Atlantic puffins: an application of habitat selection theory. MSc thesis, Memorial University of Newfoundland, St. John's

Rodway MS, Montevecchi WA, Chardine JW (1996a) Effects of investigator disturbance on breeding success of Atlantic puffins (Fratercula arctica). Biol Conserv 76:311-319

Rodway MS, Regehr HM, Chardine JW (1996b) Population census of breeding Atlantic puffins at Great Island, Newfoundland. Can Wildl Serv Tech Rep Ser Atlantic Region, Sackville

Schneider DC, Hunt GL Jr (1984) A comparison of seabird diets and foraging distribution around the Pribilof Islands, Alaska. In: Nettleship DN, Sanger GA, Springer PF (eds) Marine birds: their feeding ecology and commercial fisheries relationships. Supply and Services Canada, Ottawa, p 86-93

Templeman W (1948) The life history of the capelin (Mallotus villosus Müller) in Newfoundland waters. Nfld Gov Lab Bull 17

Weins JA, Scott JM (1975) Model estimation of energy flow in Oregon coastal seabird populations. Condor 77:439-452

Wilson RP (1984) An improved stomach pump for penguins and other seabirds. J Field Ornithol 55:109-111

Manuscript first recelved: May 28, 1996

Revised version accepted: August 27, 1996 